\section{Leaf Color Stability during Plant Development as an Index of Leaf Color Variation among Micropropagated Caladium}

\author{
Eakhlas U. Ahmed, Takahiro Hayashi, and Susumu Yazawa \\ Laboratory of Vegetable and Ornamental Horticulture, Graduate School of \\ Agriculture, Kyoto University, Oiwake-cho, Kitashirakawa, Kyoto 606-8502, \\ Japan
}

Additional index words. leaf color variants, stability, micropropagation

\begin{abstract}
The developmental pattern of leaf color distribution during plant development in 10 cultivars of Caladium xhortulanum Birdsey was investigated. We used the color occupying the largest area in the terminal leaf as the dominant color, and expressed the leaf color stability during plant development by the ratio of the percentage of the dominant color area in the terminal leaf to that of the dominant color area in the initial leaf (leaf color stability index). In some cultivars, leaf color stability index was clearly greater than 1 (leaf-color-unstable cultivar), but in some cultivars it was close to 1 (leaf-color-stable cultivar). In plants regenerated from leaf explants of leaf-color-unstable cultivars, many $(21 \%$ to $43 \%)$ color variants were observed but only a few (0\% to $6 \%)$ occurred from leaf explants of leaf-color-stable cultivars. Tissue culture appears to be a useful technique for rapid propagation based on leaf color stability in leaf-color-stable and leaf-color-unstable cultivars.
\end{abstract}

Caladium comprises about a dozen species with colorful foliage. Specimens are used to adorn the landscapes of residential and commercial settings by incorporation into landscape beds and container gardens. Only $C$. bicolor, with fancy leaves, and C. picturatum, with lance leaves, have contributed to the breeding and the development of modern cultivars (Graf, 1970). Florida is the leading producer of Caladium, supplying more than $90 \%$ of the world's tubers. Tubers are exported mainly to Europe and Japan for forcing in containers. Most Caladiums are propagated asexually from tuber pieces (chips) that are cut into $2-\mathrm{cm}$ cubes (Black and Tjia, 1979) before planting. Production of marketable Caladium tubers from chips takes 1 year or more, depending on commercial grade.

Tissue culture has emerged as the predominant method of propagating ornamental plants and has been used to rapidly propagate disease-free Caladium (Hartman, 1974). Trueto-type propagation is considered essential for commercial supply, and tissue culture-derived variation is generally undesirable. In some cases, variations produced through tissue culture can be inherited, displaying unique morphological characteristics that can not be obtained by cross-breeding (Bouman and De Klerk, 1997). Variants are highly valuable in breeding and have been established as cultivars in some floral crops (Orton, 1986). Variation among regenerated plants is often observed in plant morphology, leaf shape, and leaf variegation.

Received for publication 6 Feb. 2003. Accepted for publication 18 July 2003.
Leaf color variation in Caladium is caused primarily by changes in anthocyanin distribution in the foliage. However, chlorophyll also affects the leaf color variation. Color variation often occurs as spots, streaks, or sectors of tissue and is classified into pattern and non-pattern phenotypes. In Caladium, leaf color pattern often changes from initial to later leaves. Zhu et al. (1993a) reported leaf color variants among regenerated Caladium plants, but could not predict the performance of Caladium cultivars in tissue culture.

The following experiments were conducted to estimate in advance the degree of foliar variation during tissue culture propagation of Caladium cultivars. More than 2000 cultivars have been produced, of which some 100 are grown today (Wilfret and Hurner, 1982). Mass production of nonvariant and induction of variants useful in breeding could be considered, according to the propagator's purpose. In this paper, we propose a convenient index for judging the stability of leaf color pattern in Caladium plants propagated by tissue culture by categorizing cultivars on the basis of leaf color pattern. Prediction of phenotypic variation among plants propagated in vitro would be useful for Caladium growers.

\section{Materials and Methods}

Plant material. Ten Caladium cultivars ['Fancy Beauty', 'Costa Rica', 'Rose Bud', 'Postman Joyner', 'Miss Muffet', 'Pink Beauty', 'Hok Long', 'Pink Cloud', 'AH-9' (a somaclonal variant of 'Pink Cloud'), and 'Fire Chief'] were selected, based on leaf color stability during plant development 3 months after planting tuber pieces (Ahmed et al., 2002a). Plants were grown in $15-\mathrm{cm}$ plastic pots with a growing medium composed of vermiculite and rock wool in a glasshouse at Kyoto Univ. experimental farm.

Leaf color stability index. Six plants with six or seven leaves were selected from each cultivar, and the area of red and green pigmentation was measured on five leaves from each plant. The area of each color in a leaf was calculated and analyzed using imageanalyzing software that has been used for the analysis of leaf spot in Saintpaulia (Yun et al., 1996). Leaf color proportion was calculated using the area with red and green color. The color occupying the largest area in the terminal leaf was classified as the "dominant color." Leaf color stability during plant development was assessed by the leaf color stability index, which was the proportion of the percentage of the dominant color area in the terminal leaf to that of the dominant color area in the initial leaf. However, index = percent terminal/percent initial leaf color could be defined as leaf color stability. Stock plants or regenerants with a leaf color stability index close to 1 were considered leaf-color-stable cultivars, whereas plants assigned an index greater than 1 were considered leaf-color-unstable.

Culture ofleafexplants. Young leaves were collected from six plants of each cultivar and washed with detergent solution before surface sterilization by immersion in $0.5 \% \mathrm{NaClO}$ plus $0.8 \%$ Tween 20 for $10 \mathrm{~min}$. After three rinses with sterile distilled water, leaves were cut into $5 \times 5 \mathrm{~mm}^{2}$ pieces and placed into $60-\mathrm{mL}$ test tubes containing $20 \mathrm{~mL}$ of callus induction medium [MS macroelements (Murashige and Skoog, 1962), supplemented with Ringe and Nitsch microelements and vitamins (Ringe and Nitsch, 1968), and $20 \mathrm{~g} \cdot \mathrm{L}^{-1}$ sucrose, 5 $\mu \mathrm{M}$ naphthalene acetic acid (NAA), $5 \mu \mathrm{M} 6-$ benzyladenine (BA), and $8 \mathrm{~g} \cdot \mathrm{L}^{-1}$ agar powder (Wako Pure Chemical Industries, Osaka, Japan)]. Leaf explants were cultured at $25{ }^{\circ} \mathrm{C}$ under $25 \mu \mathrm{mol} \cdot \mathrm{m}^{-2} \cdot \mathrm{s}^{-1}$ cool-white fluorescent light. Calli were subcultured at 4-week intervals to fresh medium without NAA and BA in $6.0 \times 6.0 \times 10.0 \mathrm{~cm}$ polycarbonate boxes. After three subcultures, six to 18 regenerated plants from each cultivar were transferred to vermiculite in cell trays (cell size $5.0 \mathrm{~cm} \times 5.0$ $\mathrm{cm} \times 7.0 \mathrm{~cm} ; 50$ cells per tray) and kept in a mist house for $\approx 1$ month for hardening. Plants $\approx 2-3 \mathrm{~cm}$ high were transplanted to pot trays (pot size $9.0 \mathrm{~cm} \times 9.0 \mathrm{~cm} \times 9.0 \mathrm{~cm}$ ) filled with growth medium (vermiculite) and fertilized with $5 \mathrm{~N}-10 \mathrm{P}_{2} \mathrm{O}_{5}-5 \mathrm{~K}_{2} \mathrm{O}$ at $2 \mathrm{~mL} \cdot \mathrm{L}^{-1}$ once a week. Regenerants were grown in a glasshouse (25\% shade from sunlight) for 3 to 4 months at 25 to $35^{\circ} \mathrm{C}$ (daytime) and compared with stock plants.

Evaluation of the phenotypes of regenerated plants. Regenerants were examined for leaf color variation at the five- to six-leaf stage. Plants possessing one or more changes in color pattern from the mother plants were regarded as variants. To determine the influence of tissue culture regeneration on phenotypic stability of leaf color variants of 'Pink Cloud' propagated by tissue culture, we grew the leaf explants from the variants produced by tissue culture, and compared the regenerated plants with the 
variants (mother plants). The culture methods were identical to those described for the leaf explant culture described above.

Determination of the ploidy level. The ploidy level of mother plants and variants was determined using flow cytometry. Leaf segments $\left(\approx 1 \mathrm{~cm}^{2}\right)$ were excised from leaves of normal and variant plants, and chopped into small pieces in 4,6-diamidino-2-phenylindole (DAPI) solution (10 mm Tris- $\mathrm{HCl}$ buffer at $\mathrm{pH}$ 7.5, $0.1 \%$ Triton $\mathrm{X}-100,2 \mathrm{~mm} \mathrm{MgCl}_{2}$, and 2 $\mathrm{mg} \cdot \mathrm{L}^{-1} \mathrm{DAPI}$ ) with a scalpel to release and stain nuclei. DAPI solution containing free nuclei was filtered through a $10-\mu \mathrm{m}$ nylon mesh to remove large cell debris before assessing DNA content by flow cytometry (CA II, Partec Ltd. Münster, Germany).

Statistical analysis. Analysis of variance was performed to test differences among the cultivars. Tukey-Kramer HSD range test was used to determine differences among percentage values in various cultivars.

\section{Results and Discussion}

There are many patterns of color development in Caladium plants. However, genotypes can be categorized into two groups on the basis of leaf color distribution (Figs. 1, 2). In one group of cultivars, leaf color proportion (red : green) was uniform from initial to terminal leaves (leaf-color-stable cultivars: 'Fancy Beauty', 'Costa Rica', 'Rose Bud', 'Postman Joyner', and 'Miss Muffet'; Fig. 2A-C), but in the other group, the leaf color proportion changed markedly from initial to terminal leaf (leaf-color-unstable cultivars: 'Pink Beauty', 'Hok Long', 'Pink Cloud', 'AH-9', and 'Fire Chief'; Fig. 2D-F). In some leaf-color-unstable cultivars, the initial leaves were green with a small red area in the center, but red areas were distributed along the entire lamina in mature leaves (Fig. 2G).

Only a few variants were observed among plants regenerated from leaf explants of leafcolor-stable cultivars (Fig. 3). On the other hand, many leaf color variants were observed among regenerants from leaf-color-unstable cultivars. The percentage of leaf color variants among the regenerated plants was highly correlated with the leaf color stability index of the mother plants (Fig. 3). The leaf color stability index is a useful tool to evaluate the leaf color stability among regenerants from leaf explants.

Plants regenerated from leaf explants of leaf-color-unstable cultivars showed color variegation different from that of their mother plants. Among the regenerated plants, lamina color variants, including gray and green, were often observed. Leaf vein color variants ranged from white to green in 'Pink Cloud', and red to green in 'Pink Beauty' (Table 1). All such variants examined in this study grew normally during in vitro propagation as well as during cultivation in a greenhouse. These variants differed from mother plants only in leaf color, and many of the variants from leafcolor-stable cultivars had green leaves. These
Leaf-color-stable cultivars
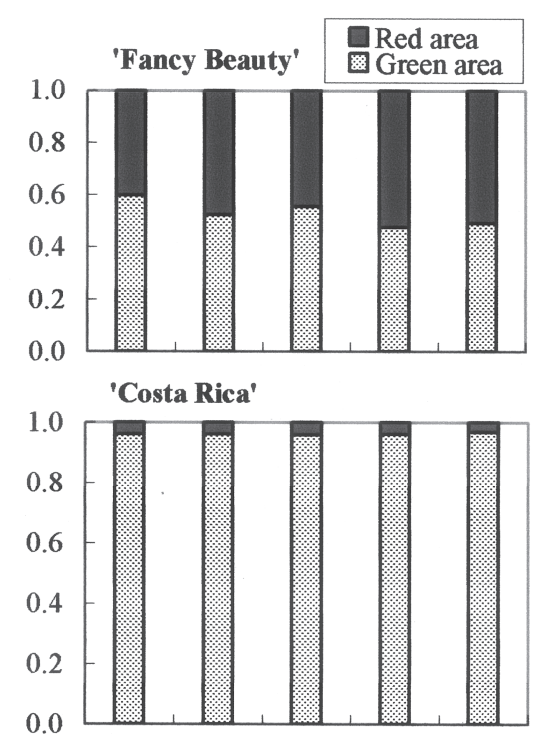

'Rose Bud'
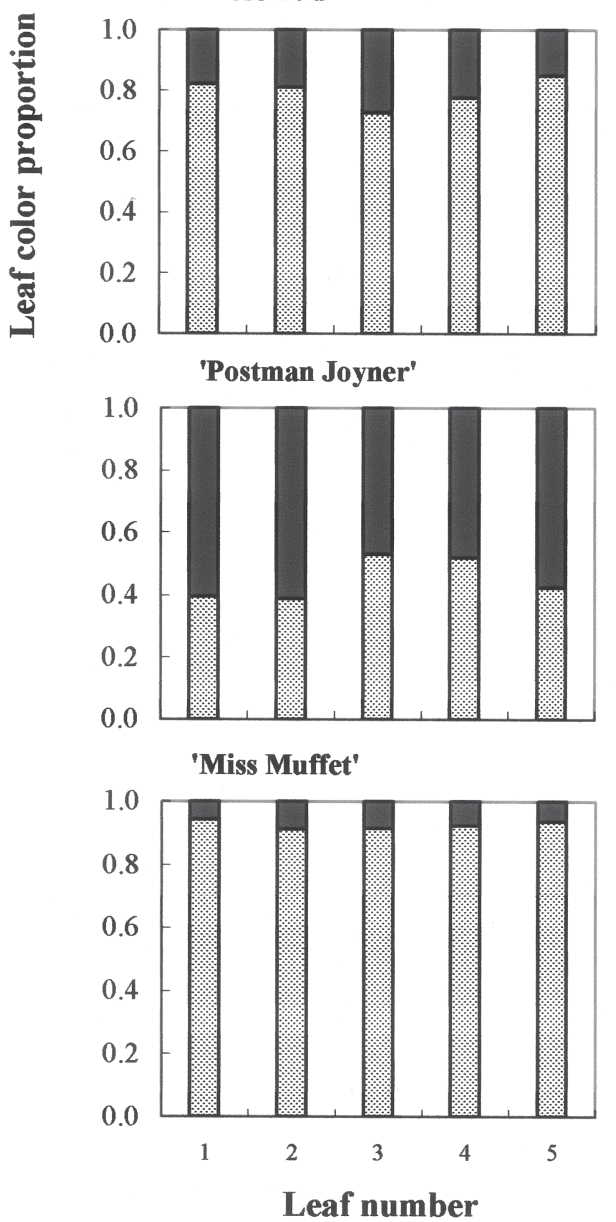

Fig. 1. Proportion of red area and green area in the leaf at each leaf number $(n=6)$. Leaves were numbered from initial (1) to terminal (5).

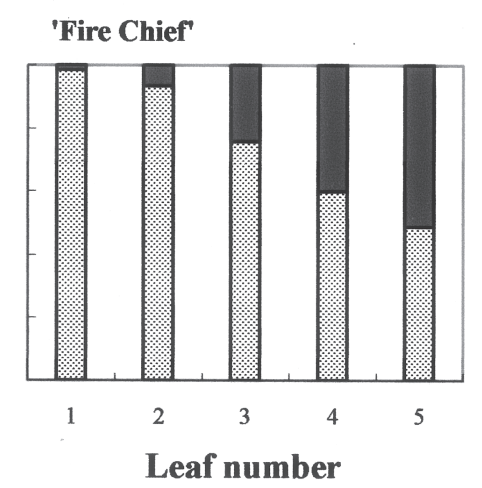

Leaf-color-unstable cultivars

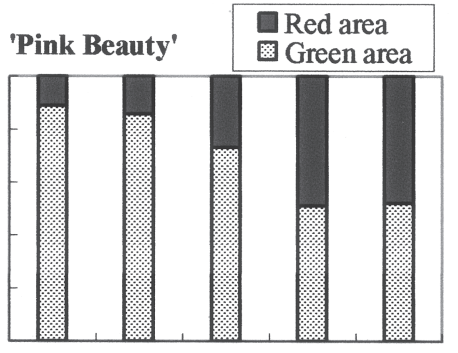

'Hok Long'

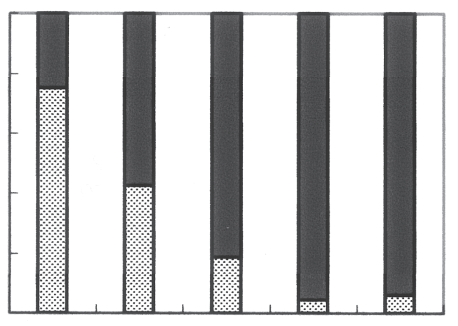

'AH-9'

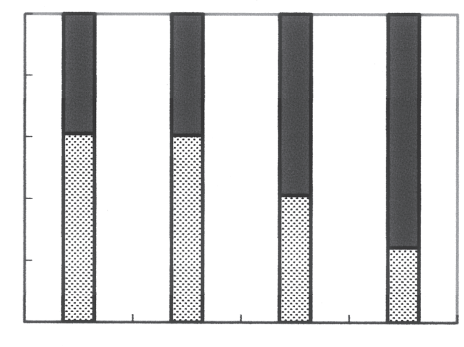

'Pink Cloud'

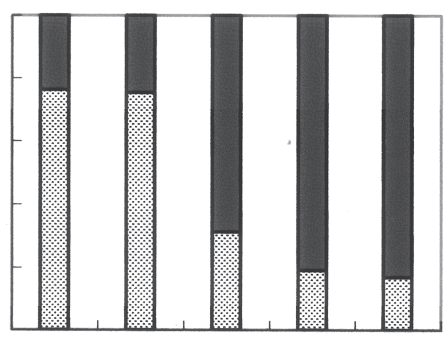

'Fire Chief' 


\section{Leaf-color-stable cultivars}
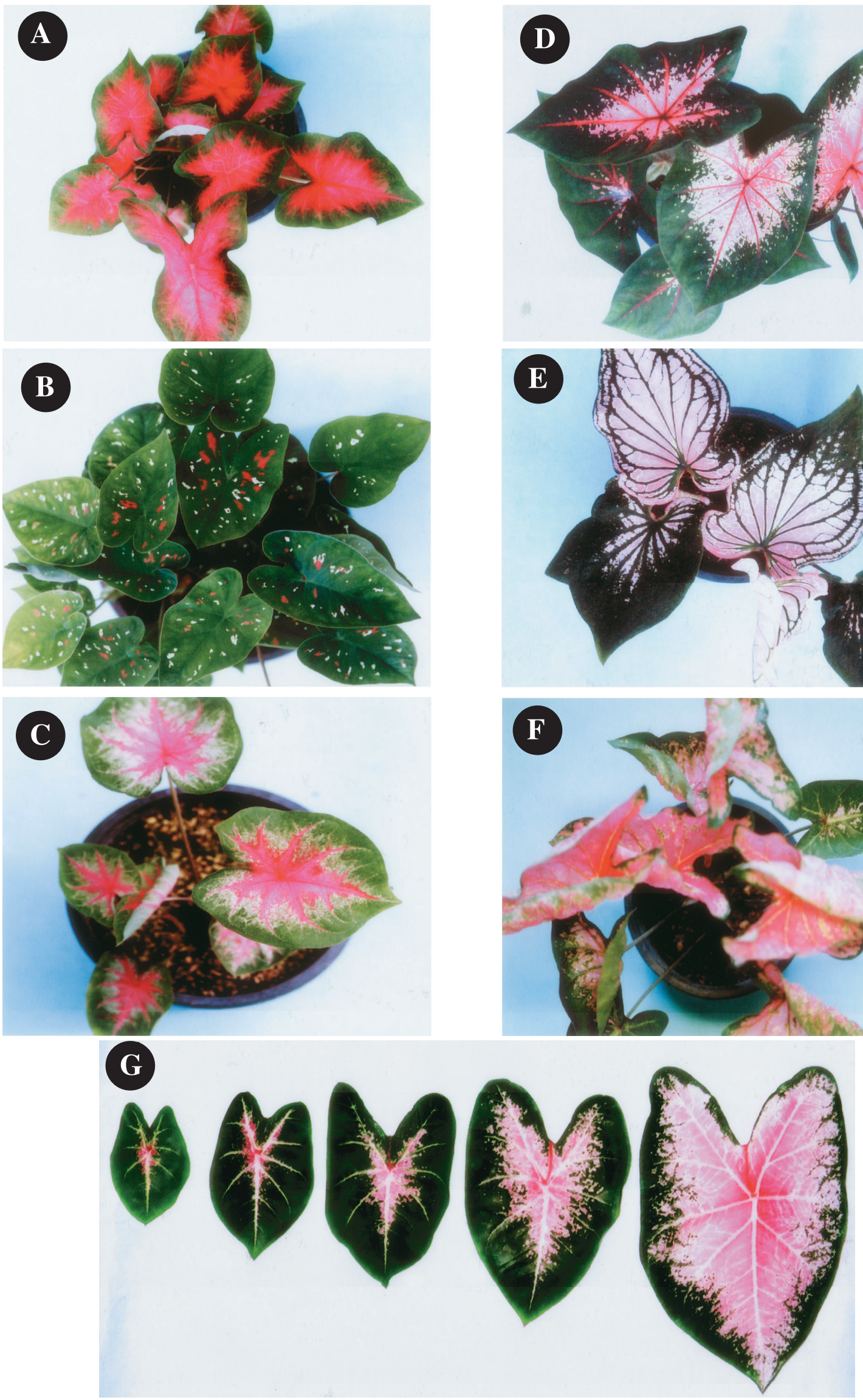

\section{Leaf-color-unstable cultivars}
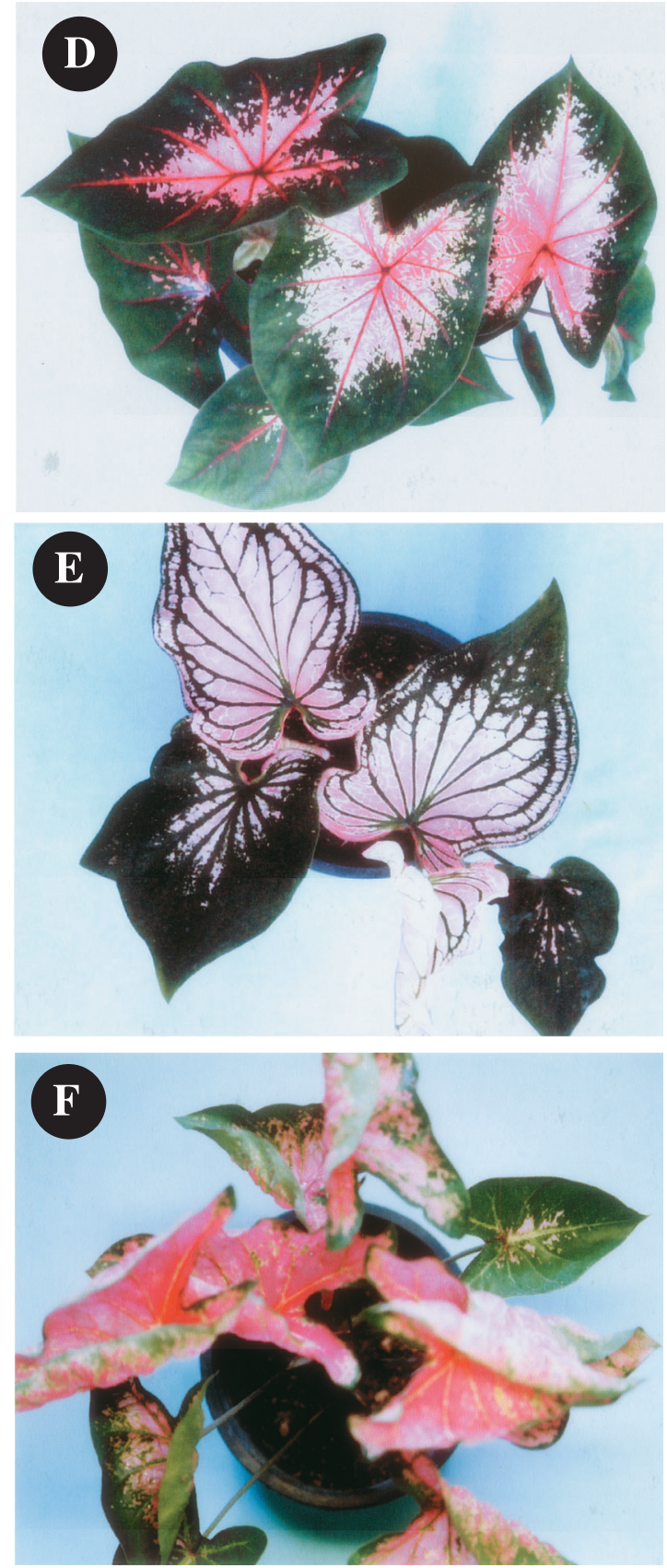

Fig. 2. Typical leaf color variegation in Caladium cultivars: (A) ‘Fancy Beauty', (B) ‘CostaRica', (C) ‘Rose Bud', (D) ‘Pink Beauty', (E) 'Hok Long', (F) ‘AH9', and (G) leaf color at each leaf number in 'Pink Cloud'. 


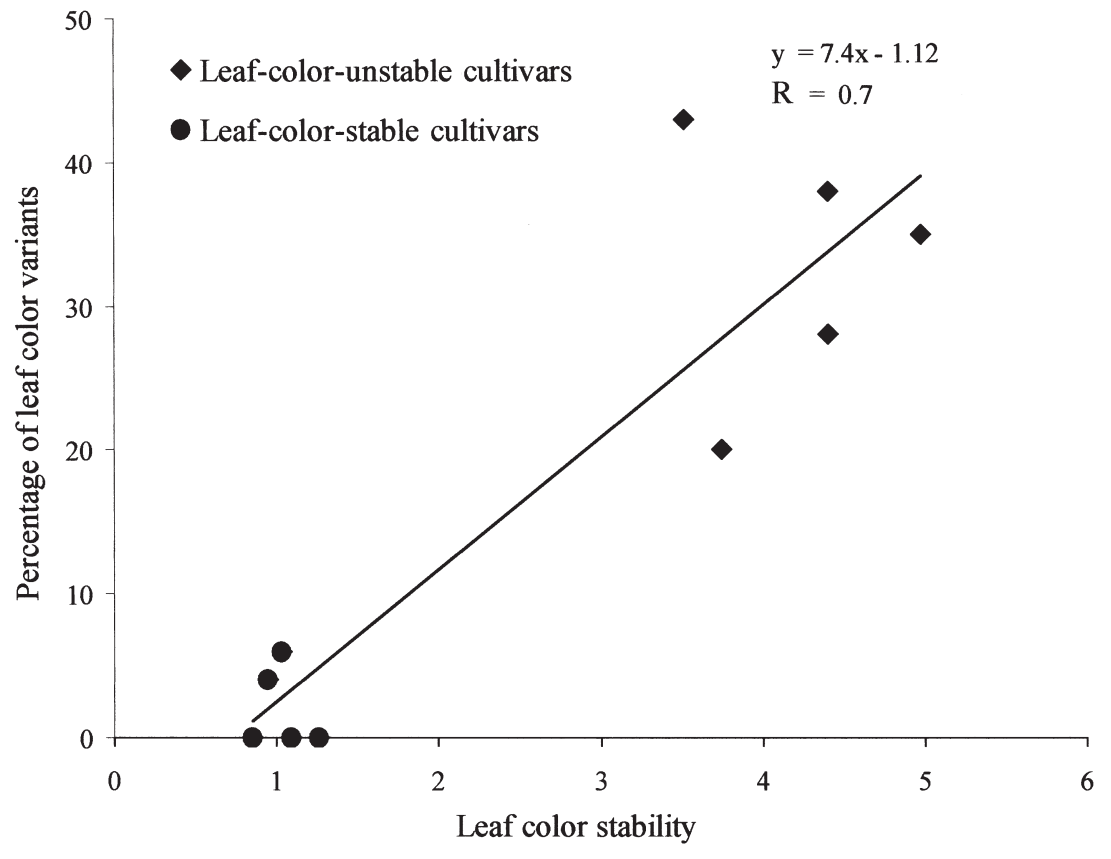

Fig. 3. Relationship between the leaf-color-stability index of the mother plant of the leaf explants and the percentage of leaf color variants in plants regenerated from leaf explants.

Table 1. Appearance of leaf color variants in the plants regenerated from the leaf explants of leaf-color-unstable Caladium cultivars.

\begin{tabular}{lccl}
\hline $\begin{array}{l}\text { Mother } \\
\text { plant }\end{array}$ & $\begin{array}{c}\text { No. of } \\
\text { regenerated plants }\end{array}$ & $\begin{array}{c}\text { Percentage } \\
\text { of variants }\end{array}$ & \multicolumn{1}{c}{$\begin{array}{c}\text { Leaf color in } \\
\text { variants }\end{array}$} \\
\hline Pink Cloud & 89 & $43 \mathrm{a}$ & $\begin{array}{l}\text { Entirely green, gray, white } \\
\text { Ped vein turned to green }\end{array}$ \\
Pink Beauty & 72 & $38 \mathrm{ab}$ & $\begin{array}{l}\text { Red } \\
\text { AH-9 }\end{array}$ \\
Fire Chief & 52 & $35 \mathrm{ab}$ & $\begin{array}{l}\text { Entirely green } \\
\text { Entirely green }\end{array}$ \\
Hok Llong & 60 & $28 \mathrm{bc}$ & Entirely green \\
\hline
\end{tabular}

${ }^{\mathrm{z}}$ Different letters within a column indicate significant differences at $P=0.05$ by Tukey-Kramer HSD test.

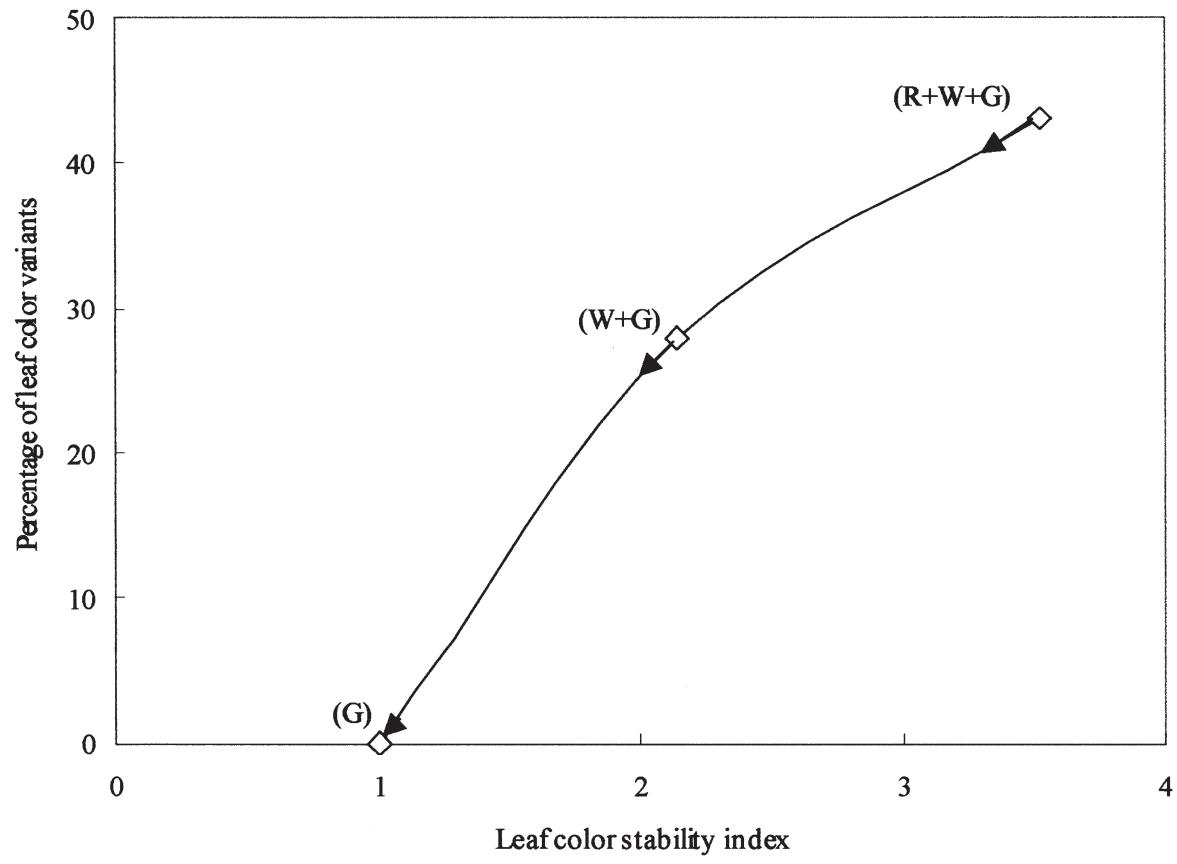

$(\mathrm{R}+\mathrm{W}+\mathrm{G})$ : Mixed leaf color (red, white, and green)

$(\mathrm{W}+\mathrm{G})$ : Gray color (white + green)

(G): Green

Fig. 4A. Percentage of variants in plants regenerated from the explants from mixed leaf color cultivars (red, white, and green), gray color cultivars (white and green), and green color cultivars. green-leaved plants may have had the genes necessary for anthocyanin formation, but they were not expressed.

Flow cytometric analysis of all variants showed that the total DNA content was the same as that of mother plants, suggesting that polyploidy was not included in the appearance of variants in this study (data not shown). Variants regenerated from leaf explants showed various kinds of leaf variation. However, D'Amato (1985) reported that in vitro culture might be useful in reducing the occurrence of somaclonal variation. The appearance of variants in Caladium plants could be reduced by using explants from younger tissue (Ahmed et al., 2002b).

Leaf color variants in plants regenerated from variegated leaf segments of Caladium have often been observed (Zhu et al., 1993b). In 'Pink Cloud', some green or gray leaf color variants were observed in plants propagated in vitro. Leaf color variants were observed at a rate of $43 \%$ in plants regenerated from plants with mixed color leaves (green, white, and red), and at a rate of $28 \%$ in the plants regenerated from gray color-variant plants (green and white). In plants regenerated from green color-variant plants, which were derived from gray color-variant plants, no variants were produced by tissue culture. The percentage of leaf color variants by tissue culture gradually decreased with the leaf color stability index (Fig. 4A). In some cases, leaf-color-unstable cultivars may evolve into leaf-color-stable plants. We observed that mixed (red, white and green) leaf color in regenerated plants gradually changed to green leaf color variants through micropropagation (Fig. 4B). Propagation by tissue culture may increase the appearance of variants, but may occasionally reduce instability. It may be concluded that there are two types of leaf color cultivars - leaf-color-stable and leaf-color-unstable - that are distinctly different in their phenotypic stability in plants regenerated by tissue culture.

The results of these experiments indicated that tissue culture is useful for rapid propagation, without producing variation in leaf-color-stable cultivars, and for the production of some superior leaf color variants in leaf-color-unstable cultivars.

\section{Literature Cited}

Ahmed, E.U., T. Hayashi, and S. Yazawa. 2002a. Leaf coloration in Caladium cultivars during plant growth and development. Bul. Expt. Farm, Kyoto Univ. 11:1-9.

Ahmed,E.U.,T. Hayashi, Y.Zhu, M. Hosokawa, and S. Yazawa. 2002b. Lower incidence of variants in Caladium bicolor Ait. plants propagated by culture of explants from younger tissue. Sci. Hort. 96: 187-194.

Black, R.J. and B. Tjia. 1979. Caladiums for Florida. Univ. of Florida Coop. Ext. Serv. Circ. No. 469. p.8.

Bouman, H. and G.-J. De Klerk. 1997. Somaclonal variation, p. 165-183. In: R.L. Geneve, J.E. Preece, and S.A. Merkle (eds.). Biotechnology of ornamental plants. CAB Intl., Oxon, U.K.

D'Amato, F. 1985. Cytogenetics of plant cell and tissue cultures and their regenerates. CRC Crit. Rev. Plant Sci. 3:73-112. 


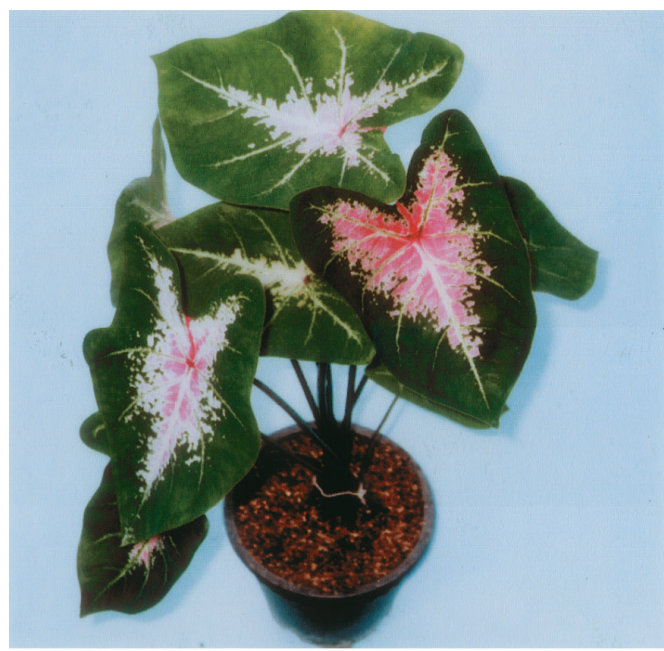

\section{Leaf-color-unstable plant}

'Pink Cloud' cultivar

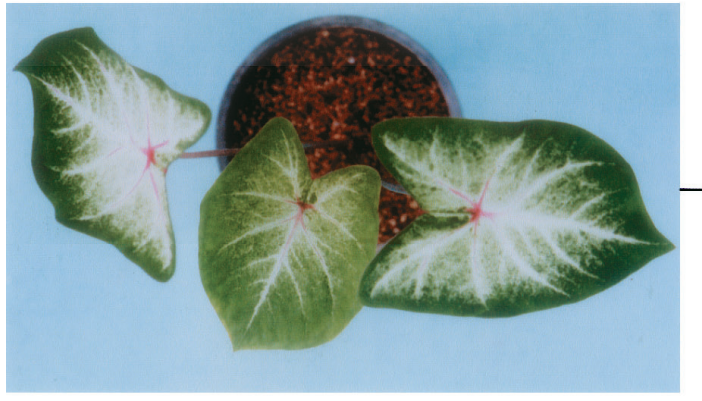

Gray leaf color variant derived from 'Pink Cloud'

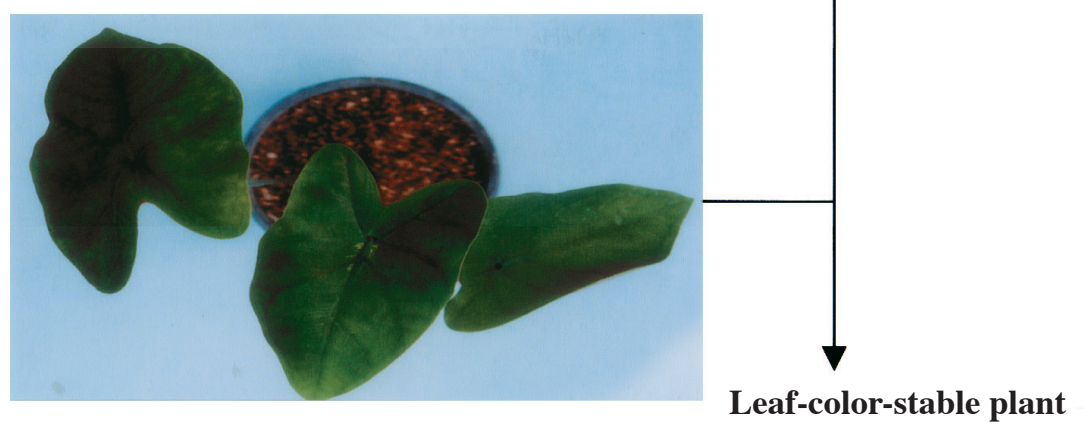

Green leaf color variant derived from a gray leaf color variant

Fig. 4B. Change from multiple to green color of the leaves of 'Pink Cloud' during micropropagation.
Graf, A.B. 1970. Caladiums, p. 1561-1563. In: Exotica Third. Roehns, E. Rutherford, N.J.

Hartman, R.D. 1974. Dasheen mosaic virus and other phytopathogens eliminated from Caladium, taro, and cocoyam by culture of shoot tips. Phytopathology 64:237-240.

Murashige, T. and F. Skoog. 1962. Arevised medium for rapid growth and tobacco tissue cultures. Physiol. Plant. 15:473-497.

Orton, T.J. 1986. Case histories of genetic variability in vitro: Celery, p. 345-366. In: I.K. Vasil (ed.). Cell culture and somatic cell genetics of plants. vol. 3.1. Academic Press, New York.

Ringe, F. and J.P. Nitsch. 1968. Conditions leading to flower formation on excised begonia fragments cultured in vitro. Plant Cell Physiol. 9:639-652.

Wilfret, G.J. and G.T. Turner, Jr. 1982. A survey of Caladium cultivars grown in Florida and their characteristics as potted plants. Proc. Florida State Hort. Soc. 95:190-194.

Yun, J.G., T. Hayashi, and S. Yazawa. 1996. Precise quantification of leaf spot in Saintpaulia by image analysis with a transmitted light. Environ. Control in Biol. 34:329-334.

Zhu, Y., S. Yazawa, and T. Asahira. 1993a. Varietal differences in leaf color variation of plants regenerated from in vitro culture of leaf blade in Caladium cultivars. J. Jpn. Soc. Hort. Sci. 62:431-435.

Zhu, Y., T. Takemoto, and S. Yazawa. 1993b. Leaf color of plants regenerated through in vitro culture from variegated leaf segments of Caladium. J. Jpn. Soc. Hort. Sci. 62:619-624. 